\title{
Plasmepsin 4-Deficient Plasmodium berghei Are Virulence Attenuated and Induce Protective Immunity against Experimental Malaria
}

\author{
Roberta Spaccapelo, ${ }^{*}$ Chris J. Janse, ${ }^{\dagger}$ \\ Sara Caterbi, ${ }^{*}$ Blandine Franke-Fayard ${ }^{\dagger}$ \\ J. Alfredo Bonilla, ${ }^{\ddagger}$ Luke M. Syphard, ${ }^{\ddagger}$ \\ Manlio Di Cristina, ${ }^{*}$ Tania Dottorini, ${ }^{,}$ \\ Andrea Savarino, ${ }^{\S}$ Antonio Cassone, ${ }^{\S}$ \\ Francesco Bistoni, ${ }^{*}$ Andrew P. Waters, ${ }^{\dagger}$ \\ John B. Dame, ${ }^{\ddagger}$ and Andrea Crisanti* ${ }^{*}$ \\ From the Department of Experimental Medicine,* University of \\ Perugia, Via Del Giochetto, Perugia, Italy; the Leiden Malaria \\ Research Group, ${ }^{\dagger}$ Department of Parasitology, Centre for \\ Infectious Diseases, Leiden University Medical Center, Leiden, \\ The Netherlands; the Department of Infectious Diseases and \\ Pathology, ${ }^{\ddagger}$ University of Florida, Gainesville, Florida; the \\ Department of Microbiology, ${ }^{\S}$ Italian National Institute of Health, \\ Rome, Italy; and the Division of Molecular and Cell Biology," \\ Imperial College, Imperial College Road, London, \\ United Kingdom
}

Plasmodium parasites lacking plasmepsin 4 (PM4), an aspartic protease that functions in the lysosomal compartment and contributes to hemoglobin digestion, have only a modest decrease in the asexual blood-stage growth rate; however, PM4 deficiency in the rodent malaria parasite Plasmodium berghei results in significantly less virulence than that for the parental parasite. $P$. berghei $\Delta p m 4$ parasites failed to induce experimental cerebral malaria (ECM) in ECMsusceptible mice, and ECM-resistant mice were able to clear infections. Furthermore, after a single infection, all convalescent mice were protected against subsequent parasite challenge for at least 1 year. Realtime in vivo parasite imaging and splenectomy experiments demonstrated that protective immunity acted through antibody-mediated parasite clearance in the spleen. This work demonstrates, for the first time, that a single Plasmodium gene disruption can generate virulence-attenuated parasites that do not induce cerebral complications and, moreover, are able to stimulate strong protective immunity against subsequent challenge with wild-type parasites. Parasite blood-stage attenuation should help identify protec- tive immune responses against malaria, unravel parasite-derived factors involved in malarial pathologies, such as cerebral malaria, and potentially pave the way for blood-stage whole organism vaccines. (Am J Pathol 2010, 176:205-217; DOI: 10.2353/ajpath.2010.090504)

The digested vacuole (DV) of malaria parasites performs hemoglobin degradation, which is a crucial process for parasite growth and survival within the host erythrocyte. In Plasmodium falciparum, the most important human malaria parasite, this is achieved with the contribution of several digestive vacuole proteases including three aspartic proteinases, the plasmepsins (PM) PfPM1, PfPM2, and PfPM4 and one histo-aspartic protease, PfHAP. ${ }^{1-5}$ The plasmepsins have long been studied as potential drug targets and subjected to functional and biochemical studies with the hope that inhibiting them would halt hemoglobin digestion and result in parasite death. Surprisingly, the systematic disruption of either individual or different combinations of the plasmepsin genes did not result in any striking growth defect. Pre-

Supported by grants from the Italian Ministry of Research Programme for Relevant National Interest (2005065913_005) and for Basic Research Investments Programme (grant RBLA03C9F4_001), and the Wellcome Trust Functional Genomics Initiative (grant 66742 to A.P.W./C.J.J.). B.F.F. was supported by The Netherlands Organization for Scientific Research (ZonMw TOP grant 9120_6135). S.C. was supported by Fondazione Cassa di Risparmio di Perugia. The funders had no role in study design, data collection and analysis, decision to publish, or preparation of the manuscript.

R.S. and C.J.J. contributed equally to this work.

Accepted for publication September 8, 2009

Supplemental material for this article can be found on http://ajp. amjpathol.org.

Current address of A.P.W.: Division of Infection and Immunity, Institute of Biomedical Life Sciences \& Wellcome Centre for Molecular Parasitology, Glasgow Biomedical Research Centre, University of Glasgow, Scotland.

Address reprint requests to Roberta Spaccapelo, Ph.D., Department of Experimental Medicine, University of Perugia, Via Del Giochetto, 06122 Perugia, Italy. E-mail: roberta.spaccapelo@unipg.it; or John B. Dame, Ph.D., Department of Infectious Diseases and Pathology, University of Florida, PO Box 110880, 2015 SW 16th Ave., Gainesville, FL 32611-0880. E-mail: damej@ufl.edu. 
sumably, this is due to redundant enzyme systems for digesting hemoglobin, which involve cysteine proteases, metalloproteases, and aminopeptidases, and to the presence of multiple pathways for the uptake of extracellular amino acids. ${ }^{6-8}$ The $P$. falciparum and Plasmodium reichnowi clades differ from other Plasmodium species in that they have four genes encoding DV plasmepsins. In $P$. falciparum only the disruption of all four plasmepsin genes, which eliminates all aspartic protease activity from the DV, resulted in delayed in vitro schizont maturation accompanied by reduced formation of hemozoin (an insoluble crystal produced during hemoglobin degradation) and less efficient processing of endosomal vesicles in the DV. ${ }^{4}$

We here investigated the impact of the loss of the various functions of the DV plasmepsins on parasite virulence by disrupting the single gene encoding the DV plasmepsin $4(\mathrm{pm} 4)$ in the rodent malaria parasite Plasmodium berghei. This parasite is a well established and tractable model to study the function of Plasmodium genes in vivo and replicates several key features of human cerebral malaria. ${ }^{9,10}$ The phenotypic analysis of loss-of-function mutants has been used to gain an insight into a variety of host-parasite interactions. ${ }^{11}$ In this study, we confirm that the disruption of PM4, which results in loss of all aspartic proteinase activity targeted to its lysosomal compartments, has only a modest effect on the intraerythrocytic development of $P$. berghei parasites, but we observed dramatic differences in the virulence of these parasites compared with that of wild-type parasites. Specifically, we report the growth and multiplication characteristics of $\Delta p m 4$ parasites in different mouse strains and demonstrate that these parasites neither induce experimental cerebral malaria (ECM) in ECM-susceptible mice nor kill the host by hemolytic anemia in ECM-resistant mice. In these latter mice, $\Delta p m 4$ parasites induce a self-resolving infection, which generates spleen-dependent protective immune responses. This is the first report of a mutant $P$. berghei parasite that does not induce cerebral complications as the result of a single gene mutation.

\section{Materials and Methods}

\section{Parasites}

A number of mutant parasite lines carrying a disrupted $P$. berghei pm4 locus (PB000298.03.0) were independently generated in different laboratories. Additional parasite lines expressing the green fluorescent protein (GFP)luciferase fusion protein were generated either on the wild-type or on the $\Delta p m 4$ background. Parasites of the $P$. berghei ANKA clone 2.34 and clone cl15cy $1^{12}$ have been used as a control (wild-type) and for the generation of the $\Delta p m 4$ mutant lines. In addition, these parasites have been used to generate the transgenic wild type $\left(\mathrm{wt}^{+}\right)$ parasites (1037cl1 line) and $\mathrm{wt}^{++}$parasites (gfp-luc/cl2 line) that express a fusion protein (GFP-Luc) encompassing the GFP (mutant3) and the luciferase (LUC-IAV) coding sequence.
$\Delta p m 4 \mathrm{cl} 1$ and $\Delta p m 4 \mathrm{cl} 6$ are two $\Delta p m 4$ parasite lines deficient in expressing PM4. The pm4 gene has been disrupted by introducing the construct pRSpm4 into the genome of the $P$. berghei ANKA clone 2.34 as described below.

$688 \mathrm{cl} 2$ and $688 \mathrm{cl} 3$ are two $\Delta p m 4$ parasite lines deficient in expressing PM4. The pm4 gene has been disrupted by introducing construct pL1095 into the genome of cl15cy1 parasites as described below.

$\mathrm{wt}^{+}$(or 1037cl1) is a reference transgenic parasite line that expresses GFP-Luc under the control of the schizontspecific ama-1 promoter. The gfp-luc is inserted into the p230p locus (PB000214.00.0) on chromosome 3 of parasites of cl15cy1. This line does not contain a drugselectable marker and has been selected by flow-sorting of GFP-expressing parasites directly after transfection as described below.

1092cl4 and $1092 \mathrm{cl} 6$ are two $\Delta \mathrm{pm}^{+}$parasite lines deficient in expressing PM4. The pm4 gene has been disrupted by introducing construct pL1095 into the genome of transgenic parasites of line 1037cl1. Both lines express GFP-luciferase under the control of the schizont specific ama-1 promoter.

$\mathrm{wt}^{++}$is a reference transgenic parasite line that expresses GFP-Luc under the control of the schizont-specific ama-1 promoter. The transgene is inserted into the $c$-/d-rrna gene unit by single crossover recombination as described below. This line contains a tgdhfr/ts drug-selectable marker cassette.

\section{Mice}

Swiss-OF1 mice (OF1 ico, construct 242, age 6 weeks, Charles River Laboratories, Inc., Wilmington, MA), C57BL/6 (age 6 weeks, Charles River Laboratories, Inc.), CBA/J (age 6 to 8 weeks, Charles River Laboratories, Inc.), Swiss-CD1 (age 6 to 8 weeks; Harlan SpragueDawley, Indianapolis, IN), BALB/c (age 6 to 8 weeks; Harlan Sprague-Dawley, Indianapolis, IN), and NIH Swiss (age 6 weeks; Harlan Sprague-Dawley, Indianapolis, IN) were used. All studies in which animals are involved have been performed according to the regulations of the Dutch "Animal On Experimentation Act" and guidelines 86/609/ EEG, the Italian regulation D.L 27 January 1992, n. 116, and the US Public Health Service Policy on Humane Care and Use of Laboratory Animals, as approved by the Institutional Animal Care and Use Committee of the University of Florida.

\section{Generation of $\Delta \mathrm{pm} 4$ parasites}

\section{Parasite Lines $\Delta \mathrm{pm} 4 \mathrm{cl} 1$ and $\Delta \mathrm{pm} 4 \mathrm{cl} 6$}

These parasite lines were generated using the DNA construct pRSpm4. This construct contains the following elements (Supplemental Figure S1A, see http://ajp. amjpathol.org): i) a5'-untranslated region (UTR) 954-bp PCR fragment of the pm4 (sense 5'-CCGGGCCCTACAAAATATTTTCATAAGTTGGC-3' [Apal site is underlined] and antisense 5'-CCATCGATTTCCATTTTGAAC- 
TAATTAAAG-3' [Clal site is underlined]); ii) a $3^{\prime}$-UTR 813-bp PCR fragment of the pm4 (sense 5'-GGGAATTCTTATATATGATATATTACACGTAC-3' [EcoRI site is underlined] and antisense 5'-CGGGATCCATGGTTTTACGATTTAAACTTTC-3' [BamHI site is underlined]); and iii) the tgdhfr/ts drug-selectable marker cassette (Supplemental Figure S1A, see http://ajp.amjpathol.org). The plasmid was linearized with Sacll and Pvull and used for the generation of $\Delta p m 4$ lines. For the generation of $\Delta p m 4 \mathrm{cl} 1$ and $\Delta p m 4 \mathrm{cl}$, blood stages of the P. berghei ANKA clone 2.34 parasites were transfected with $10 \mu \mathrm{g}$ of DNA linear fragments of pRSpm4, and mutant parasites were obtained by the standard method of drug (pyrimethamine) selection in mice. ${ }^{13}$ Pyrimethamine-resistant parasites were subsequently cloned by limiting dilution. The disruption of the pm4 locus was confirmed by diagnostic PCR (data not shown) and by Southern blot analysis of BamHI (B)- and Avall (A)-digested genomic DNA (Supplemental Figure S1B, see http://ajp.amjpathol.org). Loss of expression of PM4 was confirmed by Western blot analysis as described below (data not shown).

\section{Parasite Lines 688cl2, 688c/3, 1092cl4, and 1092cl6}

These parasite lines were generated using the DNA construct pL1095. To generate the construct, we first amplified by PCR $\sim 700-\mathrm{bp}$ fragments from either end of the pm4 locus. The primers used to amplify the 5'-UTR 754-bp fragment encoding from -311 to $443 \mathrm{bp}$ were the following: sense 5'-GCATGGTACCCCTTATTAAAGAGATTGGGAAGC-3' and antisense 5'-GCATATCGATTTTCCTAATTCTGCAGTACC-3', flanked with engineered Kpnl and Clal restriction sites (underlined). The 3'-UTR 680-bp fragment was amplified using the following primers: sense $5^{\prime}$-GCATGAATTCCAGGACAAATTGAAAATGCAG-3' and antisense 5'-GCATCCGCGGATAAATTTCTTAATCTTATGGC-3'. The PCR product contained 545 bp of coding sequence, extending 135 bp into the $3^{\prime}$-UTR and flanked by EcoRI and Sacll restriction sites (underlined). These PCR products were directionally cloned into the pL0001 plasmid backbone using the restriction sites described above, placing the fragments into the construct as shown in Supplemental Figure S1C (see http://ajp.amjpathol.org), flanking the Toxoplasma gondii dihydrofolate reductase/thymidylate synthase (tgdhfr/ts) drug-selectable marker cassette. This plasmid was linearized by cleavage with Scal, Nael, and Sapl, and the $\sim 6.5-\mathrm{kb}$ fragment was purified by agarose gel electrophoresis.

For the generation of mutant lines 688 , blood-stage parasites of cl15cy 1 were transfected with 5 to $10 \mu \mathrm{g}$ of gelpurified DNA linear fragments of pL1095, and mutant parasites were obtained by the standard method of drug (pyrimethamine) selection in mice. ${ }^{13}$ Pyrimethamine-resistant parasites were subsequently cloned by limiting dilution. The correct disruption of pm4 in two clones examined (688cl2 and 688cl3) was confirmed by the failure of PCR to amplify the expected 1122-bp from the central region of the pm4 locus using primer pair $1+2$ (primer 1: $5^{\prime}$-TCCGAATATTTAACAATTCGTGC-3' and primer 2: 5'-GTTTTTTGCAACTGCAAAACC-3') under conditions for which this fragment was readily amplified from parental lines
(Supplemental Figure S1D, see http://ajp.amjpathol. org). The expected integration into the pm4 locus was verified by successfully amplifying the predicted $5^{\prime}$ and $3^{\prime}$ boundary sequences using primer pairs $3+5$ (primer 3: 5'-TTCCCTTGTGTCCTTTAAG-3' and primer 5: 5'-CGCATTATAGAGTTCATTTTAC-3') and $6+4$ (primer 4: 5'-AAGCGGAGTTTATTGTCTGTC-3' and primer 6: 5'-CACATAAAATGGCTAGTATGAATAG-3') as shown in Supplemental Figure S1D (see http://ajp. amjpathol.org). Southern blot analysis of digested DNA from wild-type, $688 \mathrm{cl} 2$, and $688 \mathrm{cl} 3$ further confirmed the predicted integration event (data not shown).

For the generation of mutant line $\Delta \mathrm{pm}^{+}$blood-stage parasites of line $1037 \mathrm{cl}^{1}{\text { ( } \mathrm{tt}^{+}}^{+}$parasites) were transfected, selected, and analyzed as described for line 688, resulting in the selection of a transgenic parasite line that expresses GFP-Luc and is deficient in PM4 expression. Two mutant clones of this line, 1092cl2 and 1092cl4, have been selected for further analysis.

The loss of PM4 expression was confirmed by Western analysis of total protein extracted from saponin-lysed blood-stage parasites. Samples were extracted in an equal volume of SDS sample buffer $(100 \mathrm{mmol} / \mathrm{L}$ Tris-Cl, $\mathrm{pH} 6.8,10 \%$ glycerol, $2 \% \mathrm{SDS}$, and $100 \mathrm{mmol} / \mathrm{L} \mathrm{2-mer-}$ captoethanol), boiled for 5 minutes, and separated by electrophoresis on 10\% acrylamide gels (Bio-Rad Laboratories, Hercules, CA). After electrophoresis, proteins in the gel were transferred to a $0.2 \mu \mathrm{mol} / \mathrm{L}$ polyvinylidene difluoride membrane. The membrane was blocked for 24 hours $(100 \mathrm{mmol} / \mathrm{L}$ Tris- $\mathrm{HCl}, \mathrm{pH} 7.5,150 \mathrm{mmol} / \mathrm{L} \mathrm{NaCl}$, $0.1 \%$ Tween 20 , and $5 \%$ powdered milk) before incubation with primary antibody. Anti-PM4 antibodies were raised in a rabbit immunized with the predicted $\mathrm{N}$-terminal peptide of the enzyme (KYEDSIELDQSLGLSC) crosslinked to carrier protein (keyhole limpet hemocyanin) and used at a dilution of 1:7,500 in blocking solution. Antibody bound to the membrane was visualized on X-ray film after incubation with a secondary antibody, goat anti-rabbit (horseradish peroxidase-conjugated), and reaction with the SuperSignal West Dura Extended Duration Substrate (Pierce Chemical, Rockford, IL). Equal loading of parasite protein samples was confirmed using anti-BiP antisera (1:10,000 dilution) provided by J. B. Adams and obtained from the Malaria Research and Reference Reagent Resource Center (MR4) (Manassas, VA), followed by incubation with goat anti-rat (horseradish peroxidaseconjugated) and developed with the chemiluminescent substrate, as above (Supplemental Figure S1E, see http://ajp.amjpathol.org).

\section{Generation of Parasites Lines Expressing Luciferase}

The transgenic parasite line $1037 \mathrm{cl} 1$ ( $\mathrm{wt}^{+}$parasites) contains the gfp-luc integrated into the p230p locus (PB000214.00.0) under the control of the schizont-specific ama1 promoter. The construct pL1156 is integrated by double crossover recombination and does not contain a drug-selectable marker gene. The DNA construct for the generation of this reporter line (Supplemental Figure 
S2A, see http://ajp.amjpathol.org) was made by replacing the $\alpha$-tubulin // promoter of pL0024 ${ }^{14}$ with the ama1 promoter (EcoRV/BamHI fragment of pL0010). The ama1gfpm3 (EcoRV/Kpnl) fragment of this plasmid was subcloned in plasmid BSSK to create plasmid BSSKama1gfp-3'utr. Finally, the eef1aa-gfp-3'utr cassette of plasmid pL0023 (pbGFP-Lucko230p-SM CON $^{12}$ ) was replaced with the Pstl/Kpnl ama1-gfp-3'utr fragment of BSSKamalgfp-3'utr to obtain pL1141. Subsequently, the gfpm3-luc$3^{\prime}$ utr ( $\mathrm{Hpal} / \mathrm{Kpnl}$ ) fragment of pL0028 (pPbgfp-luc $\mathrm{SCH}^{15}$ ) was introduced into pl1141 to create pL1156. The plasmids pL0024, pL0010, pL0023, and pL0028 can be obtained from MR4. Blood-stage parasites (cl15cy1) were transfected with $5 \mu \mathrm{g}$ of linear fragments of Kspl-digested plasmid pL1156, ${ }^{13}$ and transgenic parasites were selected by flow-sorting of GFP-expressing parasites as described. ${ }^{16}$ Flow-sorted, GFP-Luc-expressing parasites were subsequently cloned by limiting dilution. Correct integration of the construct into the p230p locus was analyzed by PCR using the following primers $831,5^{\prime}$ CTTTATTTTTCAATTACCGCC- ${ }^{\prime}, 1348,{ }^{13}$ and 824, 5'CCAAGAAGGGCGGAAAGATC-3', and by Southern analysis of restricted DNA (data not shown). Primers and sizes of the products are indicated in Supplemental Figure S2, A and B (see http://ajp.amjpathol.org). Correct timing of expression of GFP-Luc in schizonts was analyzed by determination of GFP expression during synchronized development of blood stages in live parasites using a fluorescence microscope (Leica DMRA HC "upright" microscope) as described. ${ }^{15}$

The transgenic parasite $\mathrm{wt}^{++}$line (gfp-luc/cl2) contains the gfp-luc integrated into the $c-/ d$-rrna gene unit under the control of the schizont-specific ama1 promoter. These parasites were generated using plasmid pL0028 (MRA-797, MR4) ${ }^{15}$ (Supplemental Figure S2C, see $h$ ttp:// ajp.amjpathol.org). Correct integration of the construct was analyzed by diagnostic PCR as described previously ${ }^{17}$ (Supplemental Figure S2D, see http://ajp.amjpathol.org) and Southern analysis of restricted DNA (data not shown).

\section{Growth and Multiplication of $\Delta \mathrm{pm} 4$ Blood Stages}

The asexual multiplication rate in vivo, determined during the cloning procedure, is calculated as follows. The percentage of infected erythrocytes in mice injected with a single parasite is determined at days 8 to 11 by counting Giemsa-stained blood films. The mean asexual multiplication rate per 24 hours is then calculated, assuming a total of $1.2 \times 10^{10}$ erythrocytes/mouse ( $2 \mathrm{ml}$ of blood). The percentage of infected erythrocytes in mice infected with reference lines of the ANKA strain of $P$. berghei consistently ranges between 0.5 and $2 \%$ at day 8 after infection, resulting in a mean multiplication rate of 10 per 24 hours. $^{18}$

For determination of the number of merozoites per schizont, infected blood samples containing schizonts are stained with the DNA-specific, fluorescent dye Hoechst 33258 and analyzed by flow cytometry. ${ }^{18,19}$ Infected blood (1 to $3 \%$ parasitemia) is collected from
Swiss-OF1 mice or Wistar rats by heart puncture and cultured overnight under standard culture conditions for collecting of $P$. berghei schizonts. ${ }^{20}$ After overnight culture the infected erythrocytes are separated from uninfected cells by Nycodenz density centrifugation as described $^{13}$ and fixed in $0.25(\mathrm{v} / \mathrm{V})$ glutaraldehyde solution in PBS. These samples are stained with Hoechst 33258 at a concentration of $2 \mu \mathrm{mol} / \mathrm{L}$ for 1 hour at $37^{\circ} \mathrm{C}$ and analyzed with a FACScan (LSR II, Becton Dickinson, San Jose, CA). UV excitation of the Hoechst 33258 dye is performed with an argon ion laser $(450 / 50 \mathrm{~nm})$. The fluorescence intensity of a total of 50,000 cells per sample is measured, and data analysis is performed using CellQuest software (Becton Dickinson). The mean fluorescence intensity of free merozoites and/or ring-infected erythrocytes (first peak [P1] in the fluorescence histograms) (Supplemental Figure S3, see http://ajp.amjpathol.org) is proportional to the haploid DNA value ${ }^{18}$ and is set at 1 . The number of merozoites per schizont is calculated by dividing the mean fluorescence intensity of mature schizonts (peaks P2 and P3 in the histograms) (Supplemental Figure S3, see http://ajp.amjpathol.org) by the mean fluorescence intensity of the merozoites/ring forms. ${ }^{18}$

The length of the asexual blood stage is determined in standard short-term cultures of synchronized $P$. berghei blood stages. ${ }^{18}$ In brief, cultured and purified schizonts, collected as described by Janse et al, ${ }^{13}$ are injected i.v. into the tail veins of mice. In these animals, merozoites invade within 4 hours after injection of the schizonts, giving rise to synchronized in vivo infections with a parasitemia of 0.5 to $3 \%$, containing mainly $(>90 \%)$ ring form parasites. At 2 to 4 hours after injection of the schizonts, infected blood is collected from the mice by heart puncture and incubated at a $1 \%$ cell density in complete culture medium (RPMI 1640 with 20\% fetal calf serum) for a period of 24 hours at $37^{\circ} \mathrm{C}$. At fixed time points after the start of the cultures, 1-ml samples are collected for analysis of the cell cycle by flow cytometry. ${ }^{18}$ Cells, fixed in 0.25 (v/v) glutaraldehyde solution in PBS, are stained with Hoechst 33258 at a concentration of $2 \mu \mathrm{mol} / \mathrm{L}$ for 1 hour at $37^{\circ} \mathrm{C}$ and analyzed with a FACScan (LSR II). UV excitation of Hoechst 33258 dye is performed with an argon ion laser $(450 / 50 \mathrm{~nm})$. The fluorescence intensity and size (forward/sideward scatter) of a total of 50,000 cells per sample are measured, and data analysis is performed using CellQuest software. No gate is set in the forward/ sideward scatter for size selection of erythrocytes to include the small, free merozoites for analysis. The fluorescence intensity of infected erythrocytes is proportional to the DNA content of the parasites. ${ }^{19}$ The start of schizogony (the length of the $G_{1}$ phase of trophozoites) is defined as the time point (hours postinvasion) at which the percentage of cells with more than the haploid/diploid DNA content (percentage of schizonts; gate P5 in Supplemental Figure S4, see http://ajp.amjpathol.org) had increased $>5 \%$ compared with that at the previous time point. ${ }^{18}$ The time points at which the first schizonts are mature is defined as the time point (hours postinvasion) at which the percentage of free merozoites in gate P6 (Supplemental Figure S4, see http://ajp.amjpathol.org) had increased $>5 \%$ compared with the previous time point. ${ }^{18}$ 


\section{ECM Analysis}

The development of cerebral complications was analyzed in several mouse strains that are susceptible to ECM (Swiss-OF1, Swiss-CD1, CBA/J, and C57BL/6). ECM in $P$. berghei infection is well characterized and is defined as the development of cerebral complications (drop in body temperature $<34^{\circ} \mathrm{C}$, paralysis, convulsions, and coma) at day 6 to 9 after infection of mice with $10^{4}$ to $10^{6}$ parasites. $^{21,22}$ In this study mice were infected by i.p. injection of $10^{5}$ to $10^{6}$ infected erythrocytes $(\Delta p m 4$-infected mice were also infected with a $10 \times$ higher dose than wild-type infected mice because of the lower multiplication rate of $\Delta p m 4$ parasites). The onset of cerebral complications was determined by observation of several clinical signs such as ruffled fur, hunching, wobbly gait, limb paralysis, convulsion, and coma and by measuring the drop in body temperature at day 5 to 8 after infection at 6-hour intervals. The body temperature was measured using a laboratory thermometer (model BAT-12, Physitemp Instruments Inc., Clifton, NJ) with a rectal probe (RET-2) for mice. A drop in temperature below $34^{\circ} \mathrm{C}$ is indicative of cerebral complications, ${ }^{23}$ and experiments were terminated when the body temperature dropped below this value.

Sequestration of schizonts in whole bodies of live mice and isolated organs was visualized through imaging of luciferase-expressing, transgenic parasites with an intensified charge-coupled device photon counting video camera of the in vivo imaging system (IVIS 100, Xenogen Corporation, Alameda, CA) as described previously. ${ }^{15}$ Sequestration patterns were monitored in mice with synchronized infections. Synchronized infections (1 to 3\% parasitemia) were established by injection of cultured, purified schizonts as described above. Imaging was performed between 17 and 25 hours after injection of schizonts. Imaging of individual organs, obtained by dissection from animals at 21 to 23 hours, was done as described previously. ${ }^{15}$ Imaging data were analyzed by using the programs LIVING IMAGE (Xenogen Corporation) and IGOR PRO (WaveMetrics, Lake Oswego, OR).

For histological analysis mice with asynchronous infection at day 7 postinjection were perfused first with PBS and then with $4 \%$ paraformaldehyde. The brains were removed and fixed with $4 \%$ paraformaldehyde at $4 \mathrm{C}^{\circ}$ for 16 to 18 hours, rinsed in phosphate buffer for 24 hours, and cryoprotected with 10 and $30 \%$ sucrose each for 24 hours. The brains were divided into two hemispheres and frozen tissue was cut into $30-\mu \mathrm{m}$-thick longitudinal slices on a freezing cryotome. The sections were mounted on a slide and stained with H\&E and analyzed with an upright Olympus epifluorescent/transmitted light microscope (magnification, $\times 400$ or $\times 1000$ ).

For the analysis of blood-brain barrier damage and endothelial integrity the mice with asynchronous infection at day 7 postinjection had been injected i.v. with $2 \%$ Evans Blue. ${ }^{24}$ Three hours after injection of the dye the mice were perfused through the heart with heparinized PBS, and subsequently the brain was removed ${ }^{24}$ and digital images were collected.
Bioluminescence analysis of brain from mice with asynchronous infection at day 7 postinjection was performed by an in vivo imaging system (IVIS 200, Xenogen) after extensive perfusion of the animals through the heart with heparinized PBS as described previously. ${ }^{15}$

\section{Course of $\Delta \mathrm{pm} 4$ Infections, Drug Treatment, and Challenge with Wild-Type Parasites}

The course of infection in BALB/C and NIH Swiss mice, which are not susceptible to ECM, was analyzed after either i.v. or i.p. inoculations of $10^{7}$ parasitized erythrocytes. The parasitemia (\% of infected erythrocytes) was determined by counting daily Giemsa-stained slides of tail blood. Challenge experiments were performed by i.v. injection of different doses $\left(10^{4}\right.$ up to $\left.10^{7}\right)$ of parasites: $P$. berghei (ANKA), Plasmodium yoelii 17X (MRA-426, MR4), and Plasmodium chabaudi ASS (MRA-429, MR4).

Protection immunity induced by drug treatment was analyzed in BALB/c mice injected i.p. with $10^{7}$ wild-type parasites. Eighteen days postinfection, when the parasitemia was approximately 70 to $80 \%$ (as in $\Delta p m 4$-infected animals), the mice were treated with $70 \mu \mathrm{g} / \mathrm{ml}$ pyrimethamine in the drinking water for 30 or 60 days. During this period the animals were monitored by Giemsastained slides to confirm the absence of parasites in the blood as in the $\Delta p m 4$-infected animals that spontaneously cleared the infection. One week from the end of the drug treatment the mice were challenged i.v. with $10^{7}$ $\mathrm{wt}^{++}$parasites. Load and distribution of parasites were monitored by an in vivo imaging system (IVIS 200) as described above and by Giemsa-stained slides. Imaging data were analyzed as described above.

\section{Splenectomy Experiments}

For splenectomy, naïve and convalescent $\Delta$ pm4cl6-infected BALB/c mice were anesthetized, and the spleen was removed. ${ }^{25}$ Two weeks after splenectomy the animals were infected with $10^{7}$ wild-type parasites, and the parasitemia was determined by counting Giemsa-stained blood films of tail blood.

\section{Passive Transfer of Immunoglobulin}

IgGs were purified (Protein A antibody purification kit, PURE-1A, Sigma-Aldrich) using $1.5 \mathrm{ml}$ of serum collected from BALB/c mice infected either with wild-type at day 18 after infection or with $\Delta p m 4 \mathrm{cl} 6$ parasites at day 18 and day 40 after injection (convalescent mice). Purified IgGs were injected i.p. into BALB/c mice for three consecutive days $(-1,0$, and $+1 ; 500-\mu \mathrm{g}$ dose) relative to i.v. injection of $10^{5} \mathrm{wt}^{++}$parasites. Parasite load and distribution in whole bodies of live mice were visualized through imaging of luciferase-expressing transgenic parasites at day 2 after the last immunoglobulin administration with an intensified-charge-coupled device photon counting video camera of the in vivo imaging system (IVIS 200) as described previously. ${ }^{15}$ In a second experiment $500 \mu \mathrm{g}$ 
Table 1. Growth Characteristics of Blood Stages of Wild-Type and $\Delta p m 4$ Parasites

\begin{tabular}{|c|c|c|c|c|c|c|c|}
\hline \multirow[b]{2}{*}{ Line } & \multirow{2}{*}{$\begin{array}{c}\text { In vivo } \\
\text { multiplication rate* }\end{array}$} & \multicolumn{2}{|c|}{ Start of schizogony } & \multicolumn{2}{|c|}{ First mature schizonts } & \multicolumn{2}{|c|}{ Merozoites per schizont } \\
\hline & & Hours $^{\dagger}$ & Schizonts $(\%)^{\dagger}$ & Hours $^{\ddagger}$ & Merozoites $(\%)^{\ddagger}$ & Gate P2§ & Gate P3§ \\
\hline Wild-type & $10(0)$ & $18(0)$ & $14(3)$ & ND & ND & $13.1(0.5)$ & $16.7(0.5)$ \\
\hline$\Delta p m 4$ (688cl2) & $5.8(0.5)$ & $21(0)$ & $15(3)$ & ND & ND & $13.2(0.5)$ & $17.3(0.6)$ \\
\hline $\mathrm{wt}^{+}(1037 \mathrm{cl} 1)$ & $10(0)$ & $19(0)$ & $14(2)$ & $23(0)$ & $12(2)$ & $12.7(0.4)$ & $16.6(0.4)$ \\
\hline$\Delta p m 4^{+}(1092 c / 4)$ & $7.0(0.8)$ & $22(0)$ & $15(3)$ & $26(1)$ & $11(3)$ & $12.7(0.3)$ & $16.1(0.2)$ \\
\hline
\end{tabular}

Data are mean $(S D)$.

${ }^{*}$ The multiplication rate per 24 hours is determined in mice infected with a single parasite.

tThe start of schizogony (S/M phase) was determined by flow cytometry (Supplemental Figure S4, see http://ajp.amjpathol.org) and is demonstrated by the presence of polyploid schizonts (cells with 3-16N present in P5 in Supplemental Figure S4, see http://ajp.amjpathol.org). The start of schizogony is defined as the time point (hours postinvasion) at which the percentage of cells with more than the haploid DNA content (\% of schizonts; cells in gate P5 in Supplemental Figure S4, see http://ajp.amjpathol.org) had increased more than 5\% compared with the averages of the previous time points. The percentage of schizonts in gate P5 is the mean of at least three measurements. Multiple measurements of blood samples of the haploid stages (rings and trophozoites) have shown that the percentage of cells in gate P5 has less than $2 \%$ variation.

FThe time point at which schizonts are mature is determined by flow cytometry as shown in Supplemental Figure S4 (see http://ajp.amjpathol.org) and is demonstrated by the presence of the haploid, free merozoites (gate P6 in Supplemental Figure S4, see http://ajp.amjpathol.org). This time poin is defined as the time point (hours postinfection) at which the percentage of merozoites in P6 had increased more than $5 \%$ compared with the previous time point. The percentage of merozoites in gate P6 is the mean of at least three measurements.

\$The number of merozoites per schizonts is determined in cultured parasites by flow cytometry as described in Materials and Methods and shown in Supplemental Figure S3 (see http://ajp.amjpathol.org). The mean number of merozoites is shown for schizonts present in gate P2 and in gate P3 (Supplemental Figure S3, see http://ajp.amjpathol.org).

ND, no data.

of the purified IgG was injected i.p. into BALB/c mice 2 days after i.v. injection of the $\mathrm{wt}^{++}$parasite line. Parasite distribution in live mice was visualized through imaging of luciferase-expressing transgenic parasites 1 hour after the immunoglobulin administration. Imaging data were analyzed by using the programs LIVING IMAGE and IGOR PRO. Parasitemia was determined by daily analysis of Giemsa-stained blood films.

\section{Statistical Analyses}

We analyzed statistical significance by Student's $t$ test with the GraphPad Prism software package and statistics for survival curves by MedCalc software.

\section{Results}

\section{P. berghei Mutant Parasites Deficient in Expression of Plasmepsin 4}

In this study several independent $P$. berghei mutant lines lacking PM4 ( $\Delta p m 4$ parasites) were generated by targeted disruption of the pm4 gene (Supplemental Table S1, see http://ajp.amjpathol.org). Two different DNA constructs have been used to disrupt pm4 through double crossover homologous recombination (see Materials and Methods). Correct disruption of the pm4 gene was confirmed by diagnostic PCR and Southern blot analysis (Supplemental Figure S1, see http://ajp.amjpathol.org). The absence of PM4 expression was shown by Northern analysis (data not shown) and Western analysis of bloodstage proteins (Supplemental Figure S1, see http://ajp. amjpathol.org). To monitor $\Delta p m 4$ infections in live mice by real-time in vivo imaging we have introduced a gene encoding a GFP-luciferase fusion protein to serve as a reporter protein in wild-type parasites as well as in several $\Delta p m 4$ parasite lines (Supplemental Figure S2 and Supplemental Table S1, see http://ajp.amjpathol.org).
These luciferase-expressing parasites have been used to analyze parasite load and distribution and patterns of schizont sequestration by in vivo imaging as described previously. ${ }^{15}$

\section{Modest Growth Delay of Blood Stages of $\Delta \mathrm{pm} 4$ Parasites}

The in vivo asexual multiplication rate of $\Delta p m 4$ parasites, defined as the fold increase in parasite numbers in mice during the first 8 to 11 days after infection with a single parasite, was reduced (Table 1). Our results showed a multiplication rate ranging from a 5.8- to a 7.0-fold increase per 24 hours in $\Delta p m 4$ parasites compared with a consistent 10-fold increase in wild-type parasites. ${ }^{18}$ Flow cytometry analysis of cell cycle progression, following in vitro synchronized Hoechst 33258-stained blood-stage parasites, ${ }^{18}$ revealed that $\Delta p m 4$ parasites have a prolonged cell cycle as shown by the delay in the onset of schizogony (length of the $G_{1}$ phase) by approximately 3 hours and a similar delay in the production of mature schizonts (end of the S/M phase) (Table 1 and Supplemental Figure S4, see http://ajp.amjpathol.org). However, mature $\Delta p m 4$ schizonts had normal numbers of daughter merozoites $^{12-20}$ (Table 1; Supplemental Figure S3, see http://ajp.amjpathol.org). Interestingly, in synchronous cultures the development of $\Delta p m 4$ schizonts seemed to be less "synchronous" than in the wild-type cultures. Analysis of Giemsa-stained samples from the cultures showed that 20 to $40 \%$ of the $\Delta p m 4$ schizonts did not complete the cell division process within a 30 -hour period compared with only 8 to $12 \%$ of wild-type parasites. A prolonged, less synchronized cell cycle in combination with a delayed and somewhat reduced schizont maturation process explain the observation of the slightly reduced multiplication rate in vivo. These results also demonstrate that the lysosomal plasmepsin, PM4, is not 
A
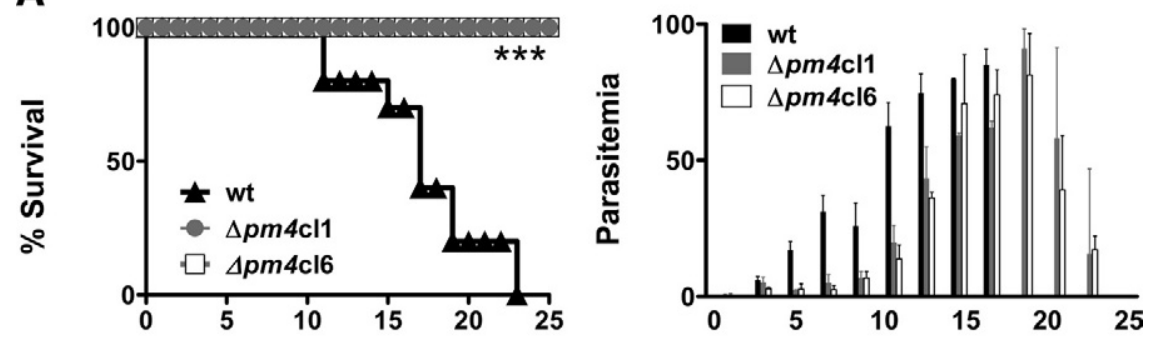

B
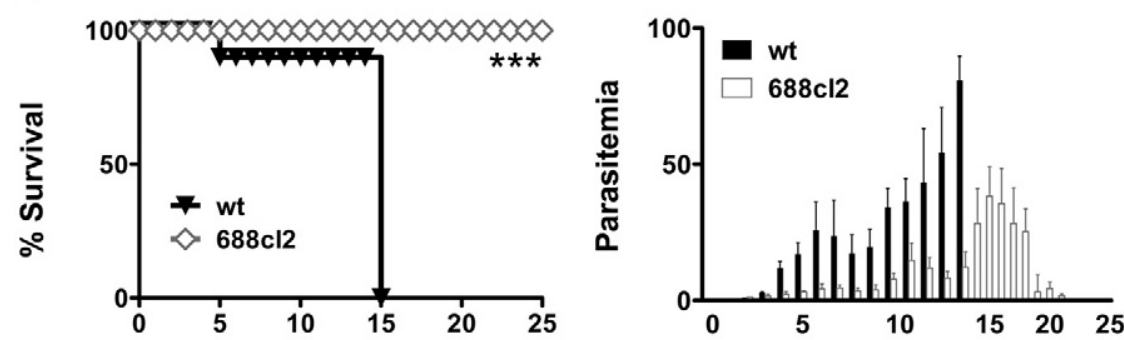

C

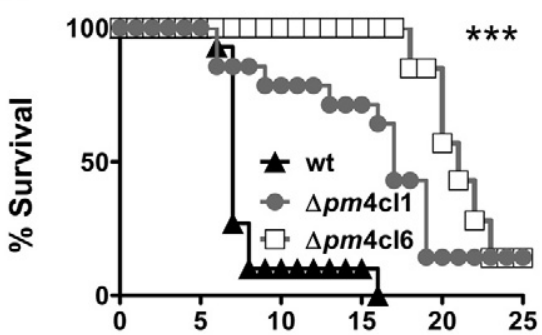

D

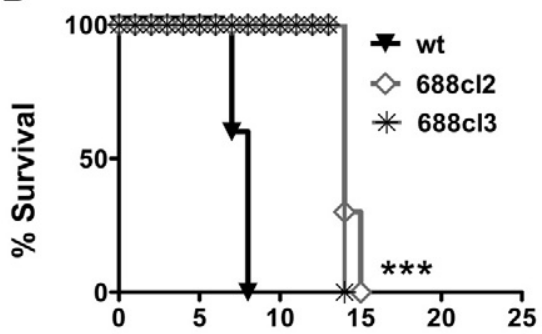

Time post infection (days)
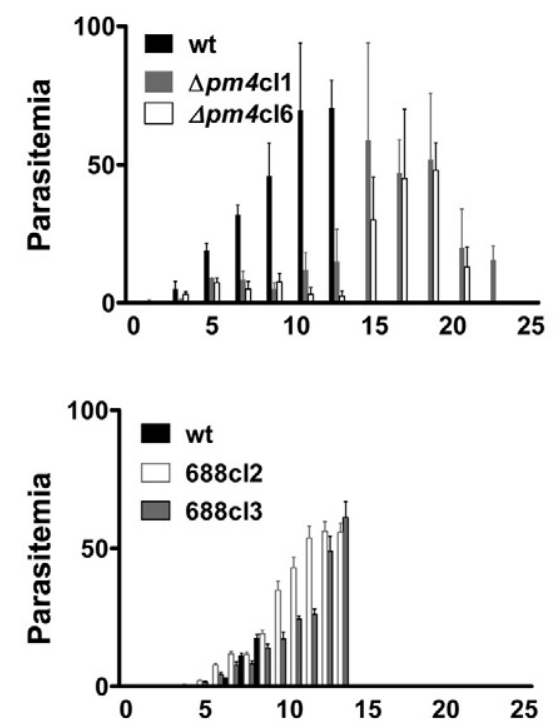

Time post infection (days)
Figure 1. The course of infection of $\Delta p m 4$ parasites in different mouse lines/parasite strains combinations. Cumulative death and parasitemia levels are shown in the left and right panels, respectively. A: $\mathrm{BALB} / \mathrm{c}$ mice infected with $10^{7}$ wild-type (wt) $(n=30)$ or $\Delta p m 4$ parasites of lines $\Delta p m 4 \mathrm{cl} 1(n=50)$ and $\Delta p m 4 \mathrm{cl} 6$ $(n=50)$. All wild-type infected mice died within the 3 rd week after infection with high parasitemia, whereas all mice infected with $\Delta p m 4$ parasites survived infection. B: NIH Swiss mice infected with $10^{7}$ wild-type (cl15cy1) $(n=10)$ or $\Delta p m 4$ parasites of line $688 \mathrm{cl} 2(n=10)$. All NIH Swiss mice infected with wild-type (cl15cy1) parasites developed high parasitemia, and experiments were terminated on day 15 after infection at a parasitemia $80 \%$. All mice infected with $\Delta p m 4$ parasites after the peak of parasitemia were able to control the infection and completely cleared the parasites. C: $\mathrm{C} 57 \mathrm{BL} / 6$ mice infected with $10^{5}$ wild-type $(n=15)$ or $\Delta p m 4 \mathrm{cl} 1(n=15)$ and $\Delta p m 4 \mathrm{cl} 6(n=50)$ parasites Ninety percent of wild-type-infected C57BL/ 6 mice developed ECM at day 6 to 8 after infection. None of the mice infected with $\Delta p m 4$ parasites showed signs of cerebral complications. Most $\Delta p m 4$-infected mice ( $80 \%$ ) developed high parasitemia and died in the 3rd week after infection. The surviving mice cleared the parasites. D: Swiss-OF1 mice infected with either $10^{5}$ wild-type (cl15cy1) $(n=10)$ or $\Delta p m 4$ parasites of lines $688 \mathrm{cl} 2(n=13)$ or line $688 \mathrm{cl} 3(n=6)$. All Swiss-OF1 mice developed ECM at day 6 to 8 after infection at a parasitemia ranging from 15 to $20 \%$, whereas the mice infected with $\Delta p m 4$ parasites did not show cerebral complications. These mice developed high parasitemia, and experiments were terminated between day 14 and 16 after infection at a parasitemia $>30 \%$. ${ }^{\text {***: }} P<0.0001$ essential for either in vitro or in vivo intraerythrocytic development.

\section{$\Delta$ pm4 Parasites Have a Virulence-Attenuated Phenotype}

While studying the growth of $\Delta p m 4$ parasites in vivo, we observed that they differed from wild-type parasites in terms of their lethality and the occurrence of ECM. To investigate this phenotype in more detail we studied $\Delta p m 4$ infections in different mouse lines/strains that are known to be susceptible or resistant to ECM. Normally BALB/C and NIH Swiss mice do not develop ECM but die in the 3rd week from hyperparasitemia and severe anemia, whereas C57BL/6, Swiss-OF1, CBA/J, and SwissCD1 develop ECM at day 6 to 11 after infection. ${ }^{9,10}$ As expected, all BALB/c mice died between day 12 and 23 after wild-type infection with a parasitemia greater than $50 \%$, within a time frame inversely correlated with the infection dose (ie, $10^{5}$ to $10^{7}$ parasites) (Figure $1 \mathrm{~A}$ ). Conversely, all $\Delta p m 4$-infected BALB/c mice unexpectedly survived infection with a peak of parasitemia at day 16 to 22 , which was rapidly cleared thereafter from the blood, resulting in undetectable parasitemia by microscopic analysis by day 25 (Figure 1A). NIH Swiss mice were also able to resolve the $\Delta p m 4$ infections in a manner very similar to that in BALB/C mice (Figure 1B).

When ECM-susceptible mice strains (C57BL/6, SwissOF1, CBA/J, and Swiss-CD1) were infected with $\Delta p m 4$ parasites, symptoms of ECM were absent in all mice, whereas 80 to $100 \%$ of wild-type-infected mice died from ECM within 6 to 9 days after infection (Figure 1, C and D; Supplemental Figure S5, see http://ajp.amjpathol.or). The absence of ECM was not dependent on the dose of $\Delta p m 4$ 
A

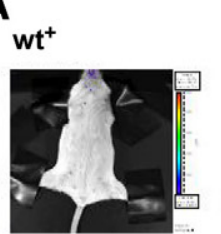

$\Delta p m 4^{+}$

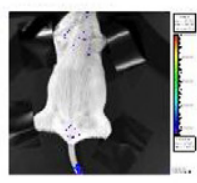

$17 \mathrm{~h}$

B

wt $^{+}$

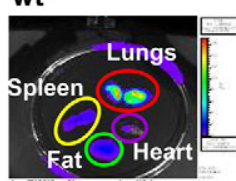

$\Delta p m 4^{+}$
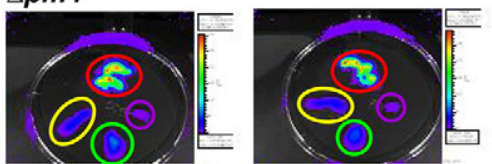

D

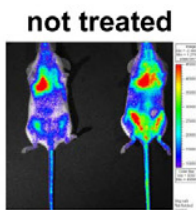

wt day +18

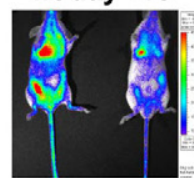

E

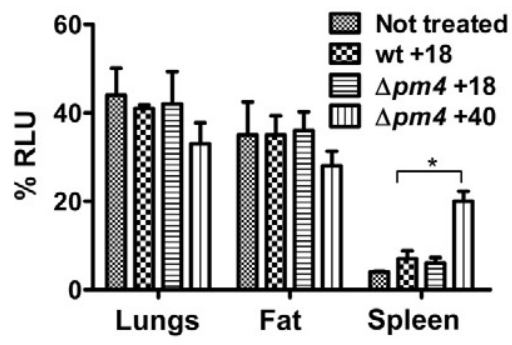

Sequestration of schizonts
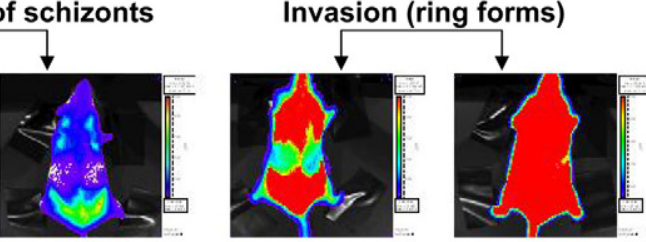

Sequestration of schizonts Invasion (ring forms)

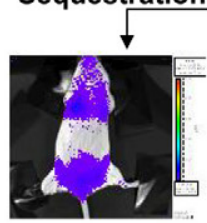

21h

C

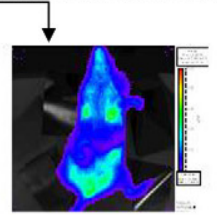

23h

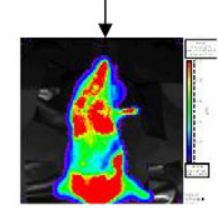

$25 h$

\section{C}

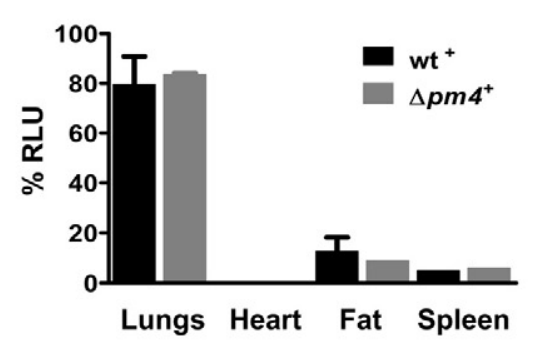

$\Delta p m 4$ day +18
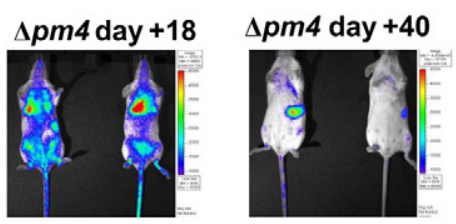

$\mathbf{F}$

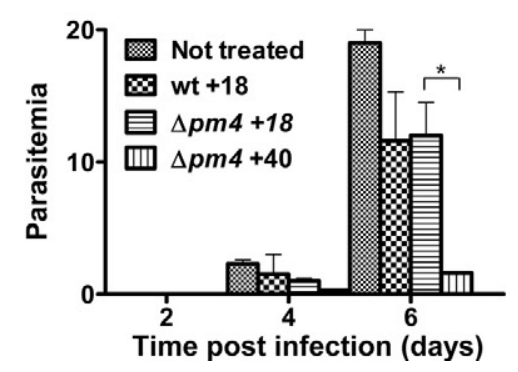

Figure 2. Distribution of luciferase expressing $\Delta p m 4^{+}$and $\mathrm{wt}^{+}$parasites in live mice as visualized by real time in vivo imaging through measurement of luciferase activity. A: A time course of an atypical distribution pattern of schizonts in mice with synchronous infections of $\Delta p m 4^{+}$and $\mathrm{wt}^{+}$parasites at different time points (hours) after the injection of purified merozoites. Schizont sequestration at 19 and 21 hours in $\mathrm{wt}^{+}$ infected mice (belly fat tissue, lungs, and spleen) and reinvasion of ring forms at 23 and 25 hours, resulting in bioluminescence in the whole body. In $\Delta p m 4^{+}$parasites schizont sequestration and invasion start later (21 and 23 hours), but the distribution remains similar. B: Bioluminescence in organs of mice infected either with $\mathrm{wt}^{+}$or $\Delta p m 4^{+}$and isolated at 21 and 23 hours after infection, respectively. C: Quantification of luciferase signals in organs of mice infected with wt ${ }^{+}$ and $\Delta p m 4^{+}$(six mice per group) showed no significant differences in parasite distribution. $\mathbf{D}$ : Parasite load and distribution in mice treated with IgG obtained from $\Delta p m 4$ convalescent mice and infected with $\mathrm{wt}^{++}$parasites. IgG purified from the serum of animals infected with $\Delta p m 4 \mathrm{cl} 6$ parasites at day 18 or 40 after injection were given to BALB/c mice at days $-1,0$, and + 1 relative to the time of i.v. inoculation with $\mathrm{wt}^{++}$parasites. As a control, mice were treated with IgG from wild-type infected mice obtained at day 18 postinfection. Nontreated: BALB/c mice infected with the $\mathrm{wt}^{++}$parasite line only Parasites were visualized at day 2 after infection of the mice with the $\mathrm{wt}^{++}$parasites. E: Quantification of luciferase signals in organs of mice (six mice per group) treated with the different IgG samples shows a significant increase in parasite accumulation in the spleen of mice treated with IgG from convalescent animals 40 days postinfection. F: The course of the parasitemia in mice treated with the different IgG samples shows a significant reduction of the parasite load in mice treated with IgG that was collected from convalescent animals (day 40 after infection). ${ }^{*} P<0.05$. RLU, relative light unit. parasites inoculated. Mice inoculated with $10^{5}, 10^{6}$, and $10^{7} \Delta$ pm4 parasites consistently failed to develop ECM, whereas as few as $10^{5}$ wild-type parasites were sufficient to cause ECM. In ECM-susceptible mice $\Delta p m 4$ parasites caused prolonged infections and most mice (80 to 90\%) died with a hyperparasitemia of more than $50 \%$ in the 3 rd week without signs and symptoms of ECM (Figure 1, C and D; and Supplemental Figure S5, see http://ajp. amjpathol.org).

To further investigate the failure of $\Delta p m 4$ parasites to cause ECM we analyzed schizont distribution in tissues and organs by real time in vivo imaging of schizonts. ECM-susceptible Swiss-OF1 mice were infected with parasites expressing the GFP-luciferase fusion gene under the control of the schizont-specific ama-1 promoter in either the wild-type or $\Delta p m 4$ genetic background, termed $\mathrm{wt}^{+}$or $\Delta p m 4^{+}$. The expression of luciferase under the schizont-specific ama-1 promoter allows the visualization of sequestered schizonts in live animals by in vivo imaging. ${ }^{15,26}$ Synchronized infections with $\mathrm{wt}^{+}$or $\Delta p m 4^{+}$parasites showed identical sequestration and distribution patterns in animals and in isolated organs. Similar to $\mathrm{wt}^{+}$, the $\Delta p m 4^{+}$schizonts sequester mainly in the lungs, adipose tissue, and spleen (Figure 2, A-C). ${ }^{15}$ The timing of sequestration of $\Delta p m 4^{+}$schizonts was delayed by a few hours (Figure 2A), in agreement with the prolonged cell cycle and delay in schizont maturation (Supplemental Figure S4, see http://ajp.amjpathol.org). Analysis of the brains of mice with synchronized infections showed the absence of schizont sequestration during the period of 20 to 24 hours after infection, both in $\Delta p m 4^{+}$- and in wt $^{+}$-infected mice (Supplemental Figure S6, see http:// 
A
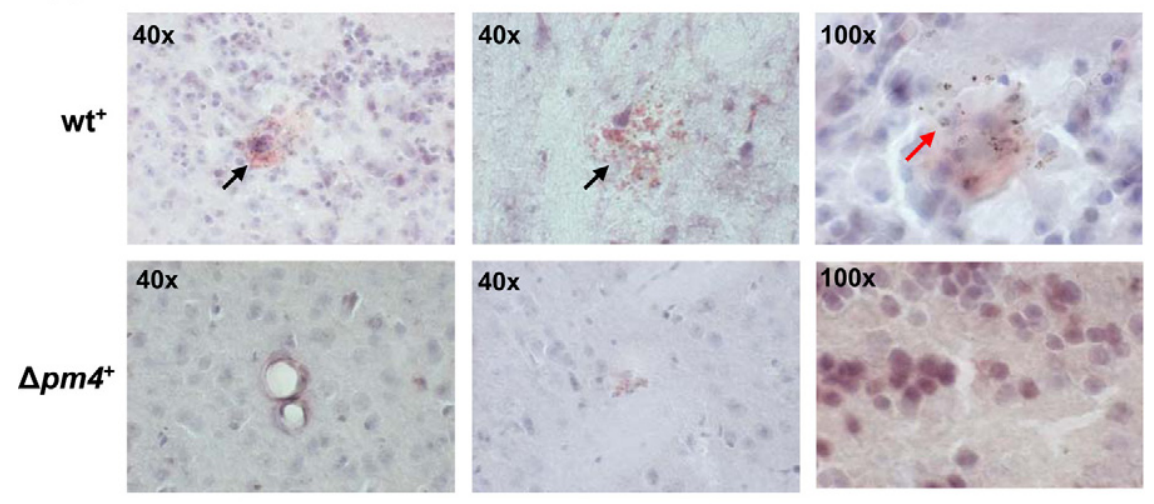

B

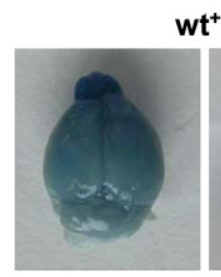

$\mathbf{w t}^{+}$
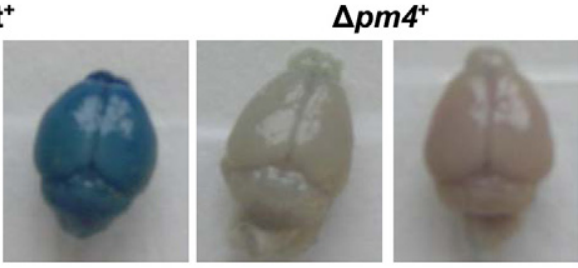

C

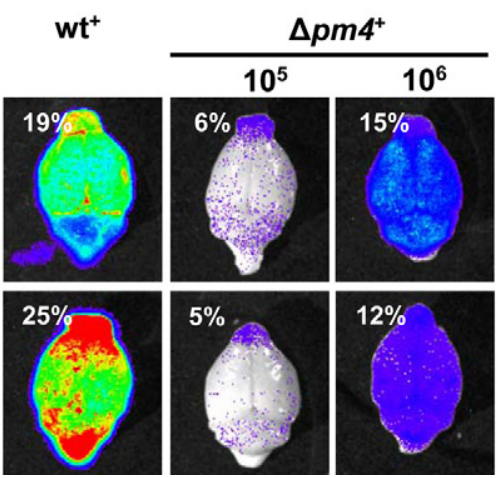

D

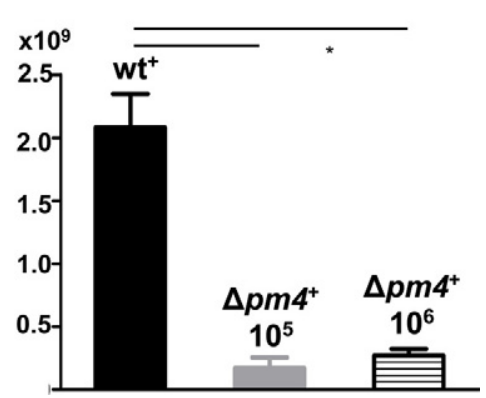

Figure 3. Analysis of cerebral complications in mice infected with wt ${ }^{+}$and $\Delta p m 4^{+}$parasites. A: Histological analysis of the brains of $\mathrm{C} 57 \mathrm{BL} / 6$ mice with asynchronous infections at day 7 after injection of $\mathrm{wt}^{+}$or $\Delta p m 4^{+}$parasites. Longitudinal sections of the brain, stained with H\&E, show extensive hemorrhagic areas in $\mathrm{wt}^{+}$-infected animals (black arrows), which are absent in $\Delta p m 4^{+}$-infected mice. In brains of $\mathrm{wt}^{+}{ }_{-}$ infected mice, infected erythrocytes, recognized by pigment granules, were found as infiltrates in brain tissue (red arrow). B: Representative digital images of Evans Blue dye extrusion analysis of brains of $\mathrm{wt}^{+}$or $\Delta p m 4^{+}$-infected $\mathrm{C} 57 \mathrm{BL} / 6$ mice at day 7 postinfection. The blue staining of the brains shows vascular leakage in $\mathrm{wt}^{+}$-infected animals, which is absent in the brains of $\Delta p m 4^{+}$-infected mice. C: Bioluminescent images of brain isolated from $\mathrm{C} 57 \mathrm{BL} / 6$ mice at day 7 after infection with $10^{5} \mathrm{wt}^{+}$or $10^{5}$ to $10^{6}$ $\Delta p m 4^{+}$parasites showing a significant higher parasite load (see $\mathbf{D}$ ) in brains of $\mathrm{wt}^{+}$than in brains of $\Delta p m 4^{+}$-infected mice as a result of differences in accumulation of infected erythrocytes in brain tissue. Percentages shown represent the parasitemias at the time of collection of the brains. D: Differences in luminescence signal between the brains of mice infected with either $\mathrm{wt}^{+}$or $\Delta p m 4^{+}$parasites $(n=6)$ showing the differences in parasite load. ${ }^{*} P<0.05$. ajp.amjpathol.org). In the above-mentioned studies the presence or absence of cerebral complications in mice was determined by the drop in body temperature and the presence of symptoms such as paralysis, convulsions, and coma. To more clearly establish that infections with $\Delta p m 4$ parasites did not induce ECM, we examined the brain of mice with nonsynchronized $\mathrm{wt}^{+}$and $\Delta p m 4^{+}$infection by histology, by in vivo imaging, and by the Evans Blue dye extrusion method for the analysis of blood-brain barrier damage and endothelial integrity. At day 7 after infection, the brains of $\mathrm{wt}^{+}$-infected mice showed clear signs of cerebral hemorrhages and vascular permeability (Figure 3, A and B). In contrast, the brains of mice infected with $10^{5}$ or $10^{6} \Delta p m 4^{+}$parasites to reach parasitemias comparable to those in the $\mathrm{wt}^{+}$-infected mice did not show signs of inflammatory damage, and we found no evidence for vascular leakage (Figure 3, A and B). Using in vivo imaging we revealed a significantly higher parasite accumulation (ie, luciferase signals) in the brains of $\mathrm{wt}^{+}$-infected mice with cerebral complications at day 7 postinfection compared with the brains of $\Delta p m 4^{+}$-infected mice without ECM (Figure 3, C and D). The higher luciferase signals indicate an increased accumulation of parasites in the brain either as a result of accu- mulation of infected erythrocytes in tissues via hemorrhages or from increased specific adherence of schizonts as a result of inflammation as described previously. ${ }^{15,16} \mathrm{Be}$ cause we imaged mice with asynchronous infections, no distinction can be made between these two possibilities because not only schizonts but also ring-infected forms contain luciferase activity as a result of carryover of the luciferase in ring forms from the schizonts.

\section{Recovery from $\Delta$ pm4 Infection Results in a Long-Lasting Malaria Immunity}

Attenuated pathogens are frequently used as vaccines, and, therefore, in this study, we tested whether the growth-attenuated $\Delta p m 4$ parasites were able to elicit protective immunity. BALB/C, C57BL/6, and NIH Swiss mice, which had recovered from a single $\Delta p m 4$ infection, were challenged with wild-type parasites. All convalescent mice of all strains tested were protected against $P$. berghei wild-type parasite challenge given at high doses ( $10^{6}$ to $10^{7}$ parasites). Challenged mice either failed to develop a detectable infection or showed a short-lasting, low-level parasitemia $(<0.05 \%)$, which was usually 
Table 2. Protection of $\Delta p m 4$ Cured Mice against Challenge with Wild-Type Parasites of P. berghei and P. yoelii

\begin{tabular}{|c|c|c|c|c|c|}
\hline Mouse strain & $\begin{array}{l}\text { Infected with/ } \\
\text { cured from }\end{array}$ & Challenged with & $\begin{array}{c}\text { Time of } \\
\text { challenge (days) }\end{array}$ & $\begin{array}{l}\text { Challenge dose } \\
\text { (no. of parasites) }^{\dagger}\end{array}$ & $\begin{array}{l}\text { No. protected/ } \\
\text { no. challenged }\end{array}$ \\
\hline $\mathrm{BALB} / \mathrm{c}$ & $\Delta p m 4 c \mid 6$ & P. berghei & 60 & $10^{7}$ & $30 / 30^{\ddagger}$ \\
\hline $\mathrm{BALB} / \mathrm{c}$ & $\Delta p m 4 c \mid 6$ & P. berghei & 120 & $10^{7}$ & $30 / 30^{\ddagger}$ \\
\hline $\mathrm{BALB} / \mathrm{c}$ & $\Delta p m 4 \mathrm{cl} 6$ & P. berghei & 180 & $10^{7}$ & $20 / 20$ \\
\hline $\mathrm{BALB} / \mathrm{c}$ & $\Delta p m 4 c \mid 6$ & P. berghei & 270 & $10^{7}$ & $9 / 9$ \\
\hline $\mathrm{BALB} / \mathrm{c}$ & $\Delta p m 4 c \mid 6$ & P. berghei & 360 & $10^{7}$ & $7 / 7$ \\
\hline C57BL/6 & $\Delta p m 4 \mathrm{cl} 6$ & P. berghei & 120 & $10^{7}$ & $10 / 10^{\ddagger}$ \\
\hline NIH Swiss & $688 \mathrm{cl} 3$ & P. berghei & $44 / 60$ & $10^{6}$ & $6 / 6$ \\
\hline $\mathrm{BALB} / \mathrm{C}$ & $\Delta p m 4 c \mid 6$ & P. yoelii (17X) & 120 & $10^{7}$ & $5 / 10$ \\
\hline $\mathrm{BALB} / \mathrm{c}$ & $\Delta p m 4 c \mid 6$ & $P$. yoelii (17X) & 120 & $10^{6}$ & $10 / 10$ \\
\hline $\mathrm{BALB} / \mathrm{c}$ & $\Delta p m 4 c \mid 6$ & P. yoelii (17X) & 120 & $10^{5}$ & $10 / 10^{\ddagger}$ \\
\hline $\mathrm{BALB} / \mathrm{c}$ & $\Delta p m 4 \mathrm{cl} 6$ & P. yoelii (17X) & 120 & $10^{4}$ & $10 / 10^{\ddagger}$ \\
\hline NIH Swiss & $688 \mathrm{cl} 3$ & $P$. yoelii (17X) & 44 & $10^{6}$ & $5 / 5$ \\
\hline
\end{tabular}

*Number of days after recovery from infection with $\Delta p m 4 \mathrm{cl} 6$ or $688 \mathrm{cl} 3$.

${ }^{\dagger}$ Mice were challenged by i.v. injection of infected erythrocytes.

FThree months after the initial challenge, 10 mice were rechallenged with $10^{7}$ parasites and all mice remained protected.

cleared within 10 days (Table 2). The immune responses elicited by $\Delta p m 4$ parasites were remarkably long-lasting. Up to 1 year after recovery from a $\Delta p m 4$ infection, the mice were protected against challenge (Table 2). The mice were also protected against challenge with the closely related species $P$. yoelii. We inoculated BALB/c mice that had recovered 4 months earlier from a $\Delta p m 4$ infection with $P$. yoelii-infected erythrocytes and found that all mice infected with $10^{4}$ to $10^{6}$ parasites were protected. Only after giving the highest challenge dose ( $10^{7}$ parasites), did we observe a mortality rate of $50 \%$ (Table 2 ). $\mathrm{NIH}$ Swiss mice that had recovered from $\Delta p m 4$ infection were also protected against challenge with $P$. yoelii. The challenge of these mice with $P$. chabaudi did not result in complete protection. However, compared with naïve mice the course of infection in $\Delta p m 4$-recovered mice was significantly milder with lower parasitemias (Supplemental Figure S7, see http://ajp.amjpathol.org). In naïve mice a parasitemia greater than $50 \%$ was observed during the first wave of parasitemia, whereas in $\Delta p m 4$-immunized mice the parasitemia remained below $10 \%$. In addition, a clear recrudescent peak was absent. We also compared the protection elicited through infection with $\Delta p m 4$ with that elicited by infection with wild-type followed by pyrimethamine drug treatment. Mice infected with wildtype parasites that were drug-treated developed a protective immunity against subsequent challenge with the $\mathrm{wt}^{++}$parasite line although we observed substantial differences compared with $\Delta p m 4$-induced protection (Supplemental Figure S8, see http://ajp.amjpathol.org). At day 30 and 60 after drug-induced recovery a challenge with wild-type parasites caused a mild but significant parasitemia (1 to $3 \%$ ) that was several fold higher than that observed after challenging $\Delta p m 4$-recovered mice $(<$ 0.05\%) (Supplemental Figure S8, see http://ajp.amjpathol.org). Furthermore, drug-treated mice failed to clear the infection for several weeks after challenge, whereas in $\Delta p m 4$-recovered mice infections were cleared in less than 10 days. These results show that mice that are infected with $\Delta p m 4$ attenuated parasites develop a stronger protective immune response than is induced in mice infected with wild-type parasites cleared by drug treatment.

\section{Protection Induced by $\Delta \mathrm{pm} 4$ Parasites Is Antibody- and Spleen-Mediated}

The nature of the immune responses elicited by $\Delta p m 4$ parasites was investigated in BALB/c mice by passive antibody transfer experiments. Specifically, naïve mice that had received purified IgG from previously infected mice were inoculated with $\mathrm{wt}^{++}$parasites to analyze the course of infection and parasite distribution by in vivo imaging. As expected, treatment with IgG collected from wild-type or $\Delta p m 4$-infected animals at day 18 after infection, had no significant effect on the parasitemia and distribution of parasites (Figure 2, D-F). Treatment of mice with $\mathrm{IgG}$ collected from $\Delta \mathrm{pm} 4$ convalescent mice (day 40 after infection) had a strong effect on both parasite distribution and parasitemia (Figure 2E and F). Most $\mathrm{wt}^{++}$parasites were removed from tissues/organs after the administration of $\lg G$ as shown by the strong decrease of luciferase activity throughout the whole body with the exception of the spleen in which luciferase activity was increased (Figure 2D). When animals were treated with IgG from convalescent mice during an ongoing $\mathrm{wt}^{++}$infection, the parasitemia rapidly decreased, and parasites accumulated specifically in the spleen within 1 hour after injection of IgG (Supplemental Figure S9, see http://ajp.amjpathol.org). These results demonstrate that in $P$. berghei infection the spleen plays an essential role in antibody-mediated clearance of infected erythrocytes from the circulation. Rather than acting on parasite growth and/or erythrocyte invasion, antibodies seem to function by enhancing the clearance of infected erythrocytes by splenic macrophages. In addition, the observation that spleens from mice infected with $\Delta p m 4$ parasites were on average twice the size of those from wild-type-infected mice (Figure 4A), emphasizing the role of the spleen in the resolution of $\Delta p m 4$ infections. The role of the spleen was further investigated by infecting splenectomized BALB/c mice with $\Delta p m 4$ parasites. These mice failed to clear $\Delta p m 4$ parasites and showed recrudescent "waves" of parasitemia ranging between 15 and $50 \%$, and more than $90 \%$ of the mice died between day 
A
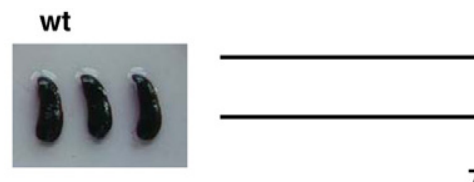

Spleen weight $\mathbf{g} \pm \mathbf{s d}$ $\Delta p m 4 \mathrm{cl6}$

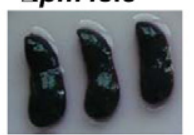

wt

$\Delta p m 4 \mathrm{cl} 6$

$0,36 \pm 0,07$

Days post infection

14

21

40

$0,70 \pm 0,08 \quad 0,80 \pm 0,10$

$0,80 \pm 0,10$

B

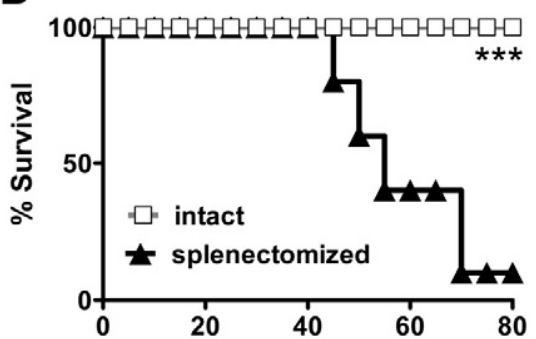

C

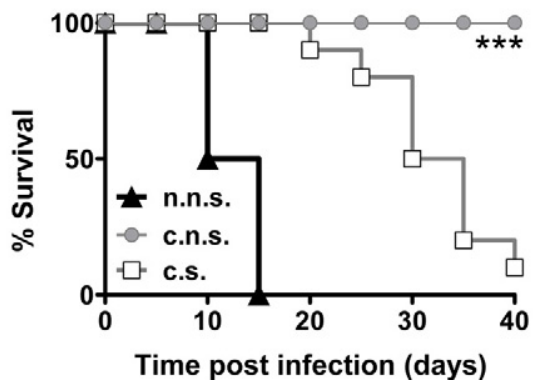

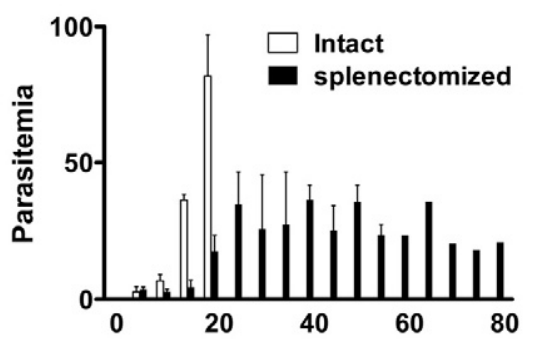

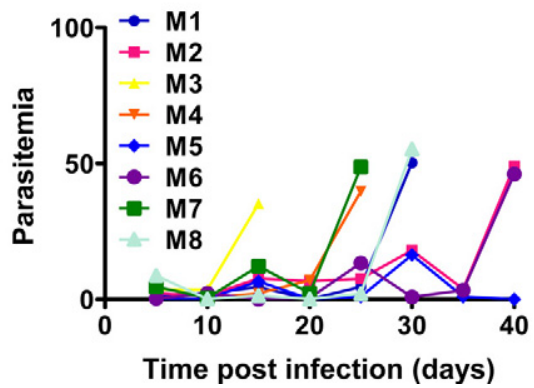

Figure 4. The role of the spleen in parasite clearance and protective immunity. A: Macroscopic observation of spleens from BALB/c mice infected with either $10^{7}$ wild-type or $\Delta p m 4 \mathrm{cl} 6$ parasites. This analysis revealed that at 21 days postinfection the spleens of $\Delta p m 4$-infected mice (lower panel) were much bigger than those from wild-type infected animals (upper panel). This observation was confirmed by comparing the spleen weight in either wild-type or $\Delta p m 4$ cl6-infected mice at different time points $(7,14,21$, and 40 days) after infection. Numbers represent the mean values $\pm \mathrm{SD}$ of spleen weight of eight animals. B: Cumulative death (left panel) and levels of parasitemia (right panel) of either intact (gray) or splenectomized (black) $\mathrm{BALB} / \mathrm{c}$ mice infected with $10^{7} \Delta p m 4 \mathrm{cl} 6$ parasites. ${ }^{* * * *} P<0.0001$. C: Cumulative death (left panel) of splenectomized $\Delta p m 4$ convalescent BALB/c mice (convalescent splenectomized [c.s.]) after a challenge with wild-type parasites. As a control $\Delta p m 4$ convalescent intact BALB/C mice (convalescent not splenectomized [c.n.s.]) and naïve intact $\mathrm{BALB} / \mathrm{C}$ mice (naïve not splenectomized [n.n.s]) were challenged with the same dose of wild-type parasites. Right panel: Time course of parasitemia in eight individual convalescent splenectomized BALB/c mice (M1M8) after a challenge with wild-type parasites. None of the $\Delta p m 4$ convalescent immune mice was able to control the parasitemia when challenged after splenectomy. All mice showed oscillating levels of parasitemia that increased sharply in a few days, leading to the death of the animals. ${ }^{* * * *} P<0.0001$.
40 and 80 (Figure 4B). When convalescent mice were splenectomized followed by challenge with wild-type parasites, protection was also abrogated. The challenge of these animals with wild-type parasites resulted in infections with an oscillating parasitemia, ranging between 1 and 10\% for a few days, followed by a rise of parasitemia to $>50 \%$ that was invariably associated with death (Figure 4C).

\section{Discussion}

We targeted for gene disruption in $P$. berghei its single blood-stage digestive vacuole aspartic protease, plasmepsin 4. Unexpectedly, despite the relatively minor parasite developmental consequences of the absence of PM4, we observed a marked effect on the virulence of these parasites both in ECM-resistant and ECM-susceptible mice. To date only a few mutant rodent parasites have been described in which disruption of a single parasite gene affects blood-stage growth in vivo. Recently, a mutant $P$. yoelii parasite that showed an attenuated phenotype in blood stages was generated by gene disruption. ${ }^{27}$ Disruption of the gene encoding purine nucleoside phosphorylase in the lethal P. yoelii YM strain resulted in impairment of parasite growth. Mice infected with this $\Delta$ pnp parasite were able to clear the infection and induce protective immune responses. $P$. berghei parasites that lack one of the two identical gene copies encoding eEF1A ${ }^{18,28}$ showed a retarded proliferation and a prolonged cell cycle up to $20 \%$, but these parasites were as virulent as wild-type parasites in mice and retained their ability to induce cerebral malaria. Therefore, the reduced growth rate alone does not explain the absence of ECM in $\Delta p m 4$-infected mice and the attenuated virulence phenotype. Investigations in mouse models of malaria have shown that ECM is a complex neurological syndrome involving interactions between cytokines and the local cellular microenvironment. ${ }^{10,21,29}$ Recently, it has been demonstrated that regulatory $T$ cells contribute to ECM by modulating immune responses, and depletion of these cells can protect mice from ECM. ${ }^{30}$ Although the role of host molecules in immunopathology (eg, interferon- $\gamma$, lymphotoxin- $\alpha$, tumor necrosis factor- $\alpha$, IL-10, and $\mathrm{IL}-12)^{21}$ is well documented, the parasite-derived molecules that trigger host responses leading to ECM pathology are essentially unknown. In $P$. falciparum infections, PfEMP1-mediated cytoadherence of schizonts in the brain has been proposed as an important parasite mediator of cerebral pathology. ${ }^{29}$ Although $P$. berghei schizonts also have a clear cytoadherence phenotype, they mainly sequester in the lungs, adipose tissue, and spleen and not in the brain vasculature. This suggests, as has been concluded previously, that cerebral pathology is unlinked to (CD36-mediated) sequestration. ${ }^{15}$ The $\Delta p m 4$ parasites show a sequestration pattern comparable with that of wild-type parasites but fail to induce ECM, indicating the absence of an obvious link between ECM and 
cytoadherence in this experimental model. It has been suggested that parasite-derived "toxins" provide the essential trigger for the proinflammatory cytokine release that leads to ECM. ${ }^{29}$ For example, several studies have implicated glycosylphosphatidylinositol anchors in the induction of tumor necrosis factor production by macrophages and increase in inducible nitric oxide synthase synthesis. $^{31,32}$ Furthermore, vaccination with the synthetic glycan moiety of glycosylphosphatidylinositol protected mice from ECM. ${ }^{33}$ In addition, the hemozoin pigment granule produced by Plasmodium has been reported to induce proinflammatory immune responses. ${ }^{34,35}$ Interestingly, P. falciparum mutants that lack all DV aspartic protease activity produce less hemozoin than wild-type parasites. ${ }^{4}$ The extent of hemozoin production in the $\Delta p m 4$ parasites is not known, but the schizonts of these parasites seem to have smaller and more widely dispersed aggregates of hemozoin (C. J. Janse, unpublished observations). It is tempting to speculate that reduced hemozoin formation would prevent the induction of ECM. However, further studies are required to identify the critical parasite toxin that is missing in the $\Delta p m 4$ parasites and is responsible for the "lack of ECM" phenotype.

The spontaneous recovery from an infection caused by $\Delta p m 4$ parasites in BALB/c and $\mathrm{NIH}$ Swiss mice is accompanied with a long-lasting protective immunity against challenge with wild-type parasites. This phenotype shares some similarities with a virulence-attenuated $P$. berghei parasite (XAT) that was generated by radiation mutagenesis as well as the $P$. yoelii parasites lacking purine nucleoside phosphorylase. ${ }^{36,37}$ The XAT and $\Delta$ pnp parasites were similarly characterized by an impaired growth rate in vivo, which also produced a self-resolving infection and induced a longlasting immunity. Although XAT parasites demonstrated the possibility of generating virulence-attenuated parasites, they have been of limited use in understanding the molecular basis of virulence or immune mechanisms, leading to protective immunity. In XAT parasites the molecular basis of parasite attenuation is unknown and is difficult to disentangle from the numerous as yet uncharacterized DNA alterations induced by ionizing radiation. In contrast, $\Delta p m 4$ and $\Delta p n p$ parasites represent molecularly characterized experimental models; the further use of these parasites should provide more insights into parasite-derived factors that induce ECM as well mechanisms of protective immunity.

Through the combination of passive IgG transfer studies, in vivo imaging, and splenectomy experiments, we showed the critical role of the spleen in protective immunity induced by $\Delta p m 4$ parasites. A marked decrease in circulating parasite load is directly associated with an increase in parasite accumulation in the spleen in mice treated with IgG from $\Delta p m 4$ convalescent mice. Rather than directly acting on parasite growth and erythrocyte invasion, these observations indicate that protective antibodies seem to function mainly by redirecting infected erythrocytes to the spleen where they are removed from the blood. The importance of antiparasite antibodies for spleen-mediated elimination of blood stages and the corresponding protective immune responses has been indicated previously for both rodent and human malaria. ${ }^{24,38-41}$ Relatively little is known about the specific mechanisms that generate adaptive immunity in the spleen during a malaria infection. Our results indicate that $\Delta p m 4$ parasites are suitable tools to investigate the specific immune mechanisms in the spleen crucial for the development of protective immunity. The knowledge from such studies might inform rational vaccine design and strategies that would reduce or abolish malarial pathology.

The limited success in generating protective immunity using so-called subunit vaccines, principally composed of one or a few parasite molecules (or indeed domains of molecules), has renewed an interest in use of whole attenuated parasite vaccines. Encouraging results have come from immunization with attenuated sporozoite vaccines both in mice and humans. These attenuated parasites, generated through irradiation ${ }^{42,43}$ and more recently by genetic modification ${ }^{44-48}$ or chemical attenuation ${ }^{49}$ are able to induce long-lasting sterile protective immunity against liverstage infection. This study and the recent report on $P$. yoelii $\Delta p n p$ mutants demonstrate that it is possible, by engineered inactivation of parasite proteins, to generate attenuated blood-stage parasites that are capable of inducing protective immunity against blood-stage infection. Such parasites should be powerful tools in elucidating parasitederived factors that cause severe disease and should provide additional insight into factors that are required to induce protective immunity. Clearly, much is still to be understood, but the insights generated by virulence-attenuated parasites, such as the one described in this study, may help to assess the potential of generating malaria vaccine based on genetically attenuated blood stages.

\section{Acknowledgments}

MR4 provided plasmid pL0028, BiP antisera was contributed by John $\mathrm{H}$. Adams, and P. chabaudi ASS was contributed by Wallace Peters and Brian L. Robinson. Jai Ramesar is acknowledged for the technical support with transfections and analysis of growth characteristics of the blood stage, Mario Rende and Anna Stabile for histological analyses, and Shahid Khan for stimulating discussions.

\section{References}

1. Coombs GH, Goldberg DE, Klemba M, Berry C, Kay J, Mottram JC: Aspartic proteases of Plasmodium falciparum and other parasitic protozoa as drug targets. Trends Parasitol 2001, 17:532-537

2. Banerjee R, Liu J, Beatty W, Pelosof L, Klemba M, Goldberg DE: Four plasmepsins are active in the Plasmodium falciparum food vacuole, including a protease with an active-site histidine. Proc Natl Acad Sci USA 2002, 99:990-995

3. Dame JB, Yowell CA, Omara-Opyene L, Carlton JM, Cooper RA, Li T: Plasmepsin 4, the food vacuole aspartic proteinase found in all Plasmodium spp. infecting man. Mol Biochem Parasitol 2003, 130:1-12

4. Bonilla JA, Bonilla TD, Yowell CA, Fujioka H, Dame JB: Critical roles for the digestive vacuole plasmepsins of Plasmodium falciparum in vacuolar function. Mol Microbiol 2007, 65:64-75

5. Liu J, Istvan ES, Gluzman IY, Gross J, Goldberg DE: Plasmodium falciparum ensures its amino acid supply with multiple acquisition pathways and redundant proteolytic enzyme systems. Proc Natl Acad Sci USA 2006, 103:8840-8845

6. Omara-Opyene AL, Moura PA, Sulsona CR, Bonilla JA, Yowell CA, Fujioka H, Fidock DA, Dame JB: Genetic disruption of the Plasmo- 
dium falciparum digestive vacuole plasmepsins demonstrates their functional redundancy. J Biol Chem 2004, 279:54088-54096

7. Liu J, Gluzman IY, Drew ME, Goldberg DE: The role of Plasmodium falciparum food vacuole plasmepsins. J Biol Chem 2005, 280: 1432-1437

8. Bonilla JA, Moura PA, Bonilla TD, Yowell CA, Fidock DA, Dame JB: Effects on growth, hemoglobin metabolism and paralogous gene expression resulting from disruption of genes encoding the digestive vacuole plasmepsins of Plasmodium falciparum. Int J Parasitol 2007, 37:317-327

9. Lou J, Lucas R, Grau GE: Pathogenesis of cerebral malaria: recent experimental data and possible applications for humans. Clin Microbiol Rev 2001, 14:810-820

10. de Souza JB, Riley EM: Cerebral malaria: the contribution of studies in animal models to our understanding of immunopathogenesis. Microbes Infect 2002, 4:291-300

11. Carvalho TG, Menard R: Manipulating the Plasmodium genome. Curr Issues Mol Biol 2005, 7:39-55

12. Janse CJ, Franke-Fayard B, Mair GR, Ramesar J, Thiel C, Engelmann S, Matuschewski K, van Gemert GJ, Sauerwein RW, Waters AP: High efficiency transfection of Plasmodium berghei facilitates novel selection procedures. Mol Biochem Parasitol 2006, 145:60-70

13. Janse CJ, Ramesar J, Waters AP: High-efficiency transfection and drug selection of genetically transformed blood stages of the rodent malaria parasite Plasmodium berghei. Nat Protoc 2006, 1:346-356

14. Kooij TW, Franke-Fayard B, Renz J, Kroeze H, van Dooren MW, Ramesar J, Augustijn KD, Janse CJ, Waters AP: Plasmodium berghei $\alpha$-tubulin II: a role in both male gamete formation and asexual blood stages. Mol Biochem Parasitol 2005, 144:16-26

15. Franke-Fayard B, Janse CJ, Cunha-Rodrigues M, Ramesar J, Buscher P, Que I, Lowik C, Voshol PJ, den Boer MA, van Duinen SG, Febbraio M, Mota MM, Waters AP: Murine malaria parasite sequestration: CD36 is the major receptor, but cerebral pathology is unlinked to sequestration. Proc Natl Acad Sci USA 2005, 102:11468-11473

16. Janse CJ, Franke-Fayard B, Waters AP, Ramesar J, Tomas AM, van der Wel AM, Thomas AW: Selection by flow-sorting of genetically transformed, GFP-expressing blood stages of the rodent malaria parasite, Plasmodium berghei. Nat Protoc 2006, 1:614-623

17. Franke-Fayard B, Trueman H, Ramesar J, Mendoza J, van der Keur $M$, van der Linden R, Sinden RE, Waters AP, Janse CJ: A Plasmodium berghei reference line that constitutively expresses GFP at a high level throughout the complete life cycle. Mol Biochem Parasitol 2004, 137:23-33

18. Janse CJ, Haghparast A, Speranca MA, Ramesar J, Kroeze H, del Portillo HA, Waters AP: Malaria parasites lacking eef1a have a normal $\mathrm{S} / \mathrm{M}$ phase yet grow more slowly due to a longer $G_{1}$ phase. Mol Microbiol 2003, 50:1539-1551

19. Janse CJ, Van Vianen PH: Flow cytometry in malaria detection. Methods Cell Biol 1994, 42:295-318

20. Janse CJ, Waters AP: Plasmodium berghei: the application of cultivation and purification techniques to molecular studies of malaria parasites. Parasitol Today 11:138-143, 1995

21. Hunt NH, Grau GE: Cytokines: accelerators and brakes in the pathogenesis of cerebral malaria. Trends Immunol 2003, 24:491-499

22. Engwerda C, Belnoue E, Gruner AC, Renia L: Experimental models of cerebral malaria. Curr Top Microbiol Immunol 2005, 297:103-143

23. Curfs $\mathrm{JH}$, van der Meide $\mathrm{PH}$, Billiau A, Meuwissen $\mathrm{JH}$, Eling WM: Plasmodium berghei: recombinant interferon- $\gamma$ and the development of parasitemia and cerebral lesions in malaria-infected mice. Exp Parasitol 77:212-223, 1993

24. Benchenane K, Berezowski V, Fernandez-Monreal M, Brillault J, Valable S, Dehouck MP, Cecchelli R, Vivien D, Touzani O, Ali C: Oxygen glucose deprivation switches the transport of tPA across the blood-brain barrier from an LRP-dependent to an increased LRP-independent process. Stroke 2005, 36:1065-1070

25. Eling WM: Chronic, patent Plasmodium berghei malaria in splenectomized mice. Infect Immun 1982, 35:880-886

26. Franke-Fayard B, Waters AP, Janse CJ: Real-time in vivo imaging of transgenic bioluminescent blood stages of rodent malaria parasites in mice. Nat Protoc 2006, 1:476-485

27. Ting LM, Gissot M, Coppi A, Sinnis P, Kim K: Attenuated Plasmodium yoelii lacking purine nucleoside phosphorylase confer protective immunity. Nat Med 2008, 14:954-958

28. Tewari R, Ogun SA, Gunaratne RS, Crisanti A, Holder AA: Disruption of Plasmodium berghei merozoite surface protein 7 gene modulates parasite growth in vivo. Blood, 2005, 105:394-396

29. Schofield L, Grau GE: Immunological processes in malaria pathogenesis. Nat Rev Immunol 2005, 5:722-735

30. Amante FH, Stanley AC, Randall LM, Zhou Y, Haque A, McSweeney K, Waters AP, Janse CJ, Good MF, Hill GR, Engwerda CR: A role for natural regulatory $T$ cells in the pathogenesis of experimental cerebral malaria. Am J Pathol 2007, 171:548-559

31. Boutlis CS, Riley EM, Anstey NM, de Souza JB: Glycosylphosphatidylinositols in malaria pathogenesis and immunity: potential for therapeutic inhibition and vaccination. Curr Top Microbiol Immunol 2005, 297:145-185

32. Riley EM, Wahl S, Perkins DJ, Schofield L: Regulating immunity to malaria. Parasite Immunol 2006, 28:35-49

33. Schofield L, Hewitt MC, Evans K, Siomos MA, Seeberger PH: Synthetic GPI as a candidate anti-toxic vaccine in a model of malaria. Nature 2002, 418:785-789

34. Coban C, Ishii KJ, Kawai T, Hemmi H, Sato S, Uematsu S, Yamamoto M, Takeuchi O, Itagaki S, Kumar N, Horii T, Akira S: Toll-like receptor 9 mediates innate immune activation by the malaria pigment hemozoin. J Exp Med 2005, 201:19-25

35. Parroche P, Lauw FN, Goutagny N, Latz E, Monks BG, Visintin A, Halmen KA, Lamphier M, Olivier M, Bartholomeu DC, Gazzinelli RT, Golenbock DT: Malaria hemozoin is immunologically inert but radically enhances innate responses by presenting malaria DNA to Tolllike receptor 9. Proc Natl Acad Sci USA 2007, 104:1919-1924

36. Waki S, Tamura J, Imanaka M, Ishikawa S, Suzuki M: Plasmodium berghei: isolation and maintenance of an irradiation attenuated strain in the nude mouse. Exp Parasitol 1982, 53:335-340

37. Yoshimoto T, Yoneto T, Waki S, Nariuchi H: Interleukin-12-dependent mechanisms in the clearance of blood-stage murine malaria parasite Plasmodium berghei XAT, an attenuated variant of P. berghei NK65. J Infect Dis 1998, 177:1674-1681

38. Quinn TC, Wyler DJ: Resolution of acute malaria (Plasmodium berghei in the rat): reversibility and spleen dependence. Am J Trop Med Hyg 1980, 29:1-4

39. Weiss L: Mechanisms of splenic control of murine malaria: cellular reactions of the spleen in lethal (strain 17XL) Plasmodium yoelii malaria in BALB/c mice, and the consequences of pre-infective splenectomy. Am J Trop Med Hyg 1989, 41:144-160

40. Engwerda CR, Beattie L, Amante FH: The importance of the spleen in malaria. Trends Parasitol 2005, 21:75-80

41. Engwerda CR, Good MF: Interactions between malaria parasites and the host immune system. Curr Opin immunol 2005, 17:381-387

42. Hoffman SL, Goh LM, Luke TC, Schneider I, Le TP, Doolan DL, Sacci J, de la Vega P, Dowler M, Paul C, Gordon DM, Stoute JA, Church LW, Sedegah M, Heppner DG, Ballou WR, Richie TL: Protection of humans against malaria by immunization with radiation-attenuated Plasmodium falciparum sporozoites. J Infect Dis 2002, 185:1155-1164

43. Wykes M, Good MF: A case for whole-parasite malaria vaccines. Int J Parasitol 2007, 37:705-712

44. Mueller AK, Labaied M, Kappe SH, Matuschewski K: Genetically modified Plasmodium parasites as a protective experimental malaria vaccine. Nature 2005, 433:164-167

45. Mueller AK, Camargo N, Kaiser K, Andorfer C, Frevert U, Matuschewski K, Kappe SH: Plasmodium liver stage developmental arrest by depletion of a protein at the parasite-host interface. Proc Natl Acad Sci USA 2005, 102:3022-3027

46. van Dijk MR, Douradinha B, Franke-Fayard B, Heussler V, van Dooren MW, van Schaijk B, van Gemert GJ, Sauerwein RW, Mota MM, Waters $A P$, Janse CJ: Genetically attenuated, P36p-deficient malarial sporozoites induce protective immunity and apoptosis of infected liver cells. Proc Natl Acad Sci USA 2005, 102:12194-12199

47. Aly AS, Mikolajczak SA, Rivera HS, Camargo N, Jacobs-Lorena V, Labaied M, Coppens I, Kappe SH: Targeted deletion of SAP1 abolishes the expression of infectivity factors necessary for successful malaria parasite liver infection. Mol Microbiol 2008, 69:152-163

48. Silvie O, Goetz K, Matuschewski K: A sporozoite asparagine-rich protein controls initiation of Plasmodium liver stage development. PLoS Pathog 2008, 4:e1000086

49. Purcell LA, Yanow SK, Lee M, Spithill TW, Rodriguez A: Chemical attenuation of Plasmodium berghei sporozoites induces sterile immunity in mice. Infect Immun 2008, 76:1193-1199 